\title{
Three Brackish-Water Ostracods (Crustacea) from Ushimado, Okayama Prefecture, Japan
}

\author{
Robin J. Smith ${ }^{1,2}$ and Takahiro Kamiya ${ }^{2}$ \\ ${ }^{1}$ Department of Zoology, Natural History Museum, \\ Cromwell Road, London, SW7 5BD, UK \\ E-mail: rjs@gn.apc.org \\ ${ }^{2}$ Department of Earth Sciences, Kanazawa University, \\ Kakuma, Kanazawa, 920-1192 Japan
}

(Received 26 February 2002; Accepted 7 October 2002)

\begin{abstract}
Three species of brackish-water ostracods, Dolerocypria mukaishimensis Okubo, 1980, Paracypria inujimensis (Okubo, 1980), and Ishizakiella supralittoralis (Schornikov, 1974), were collected from the same locality at Ushimado, Okayama Prefecture. The male of the candonid $P$. inujimensis is figured for the first time and described. This is only the second record of this species. Additionally, this report of Ishizakiella supralittoralis is the first of the species and genus from the Inland Sea of Japan; I. supralittoralis is widespread around Japan and its distribution considerably overlaps that of $I$. $m i$ urensis (Hanai, 1957). Previously, both species of Ishizakiella were presumed to have similar habitat requirements, but the distribution of 1 . supralittoralis and its coexisting species suggests that it has different habitat requirements than I. miurensis does.
\end{abstract}

Key Words: brackish, ostracods, Paracypria, Dolerocypria, Ishizakiella, ecology, distribution.

\section{Introduction}

The Cytheroidea and Cypridoidea are two of the most diversified among the eight living podocopid ostracod superfamilies, usually making up a large part of the ostracod fauna in marine and freshwater habitats, respectively. Both superfamilies have representatives in brackish-water environments as well. Ostracod faunas in such environments are typically composed of a combination of these two superfamilies, cytheroidean species being dominant in the higher salinity ranges and cypridoidean species being dominant in the lower salinity ranges (e.g., Ikeya and Hanai 1982). Apart from a few studies on mesohaline (lower salinity) habitats (e.g., Ishizaki 1969; Ikeya and Hanai 1982), and a comprehensive study on the Obitsu River Estuary (Nakao and Tsukagoshi 2002), the brackish ostracod faunas in Japan are relatively unknown. Because ostracod carapaces are usually well calcified and hence have a good preservation potential in sediments as fossils or subfossils, ostracods are particularly useful in studies of environmental changes (i.e. sea level changes and/or man-made changes); however, such studies can only be undertaken if the modern-day fauna has been studied to act as a point of reference.

Brackish water ostracods found in Ushimado, Okayama Prefecture, are the subject of this paper. A brief overview of the distribution and ecology of the 
species found is given.

\section{Material and Methods}

\section{Study area}

The material was collected from Ushimado, $34^{\circ} 38^{\prime} 22.2^{\prime \prime} \mathrm{N}, 134^{\circ} 10^{\prime} 25.1^{\prime \prime} \mathrm{E}$, Okayama Prefecture, Japan (Fig. 1). This locality is an artifical, rectangular channel running parallel with the coastline and connected to the sea via a narrow channel at its northern end. The inlet is approximately $1 \mathrm{~km}$ in length and $100 \mathrm{~m}$ wide, and is surrounded by a low-lying area covered in reeds and large numbers of discarded oyster shells. The sediment is silty mud. The inlet is influenced by the tide and the salinity presumably varies considerably along its length and through time. Abundant specimens were collected from the eastern shore of the inlet, approximately $600 \mathrm{~m}$ from the narrow channel to the sea, on 19 June 2001.

Material, methods, and terminology

Specimens were obtained by sampling the sediment with a fine-mesh net. Two hundred and seventy-four specimens were picked from the sample. Due to the lack of pronounced sexual dimorphism in the carapace shape of the two candonid species, males were identified by the presence of testes visible through the cara-

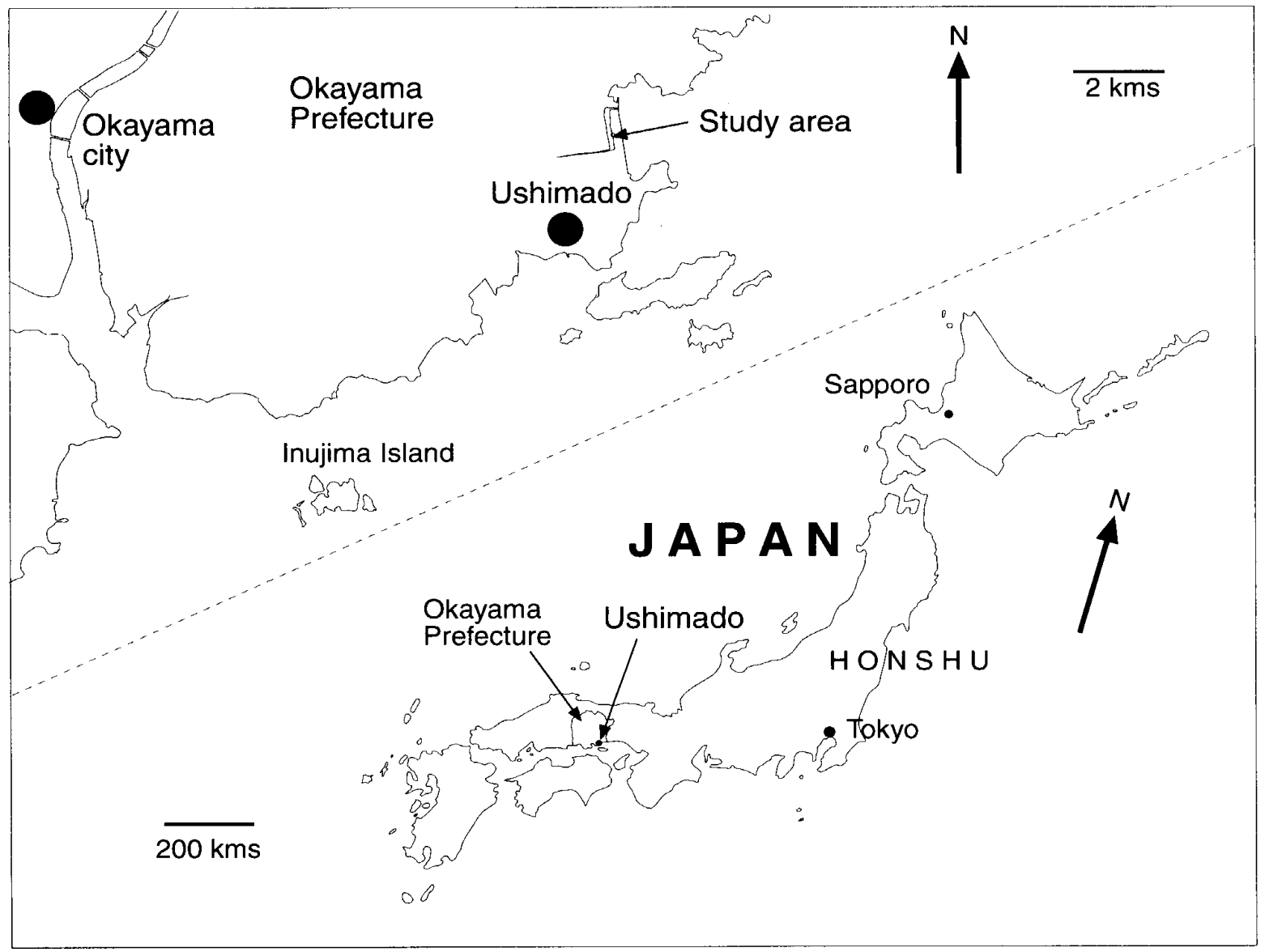

Fig. 1. Location of Ushimado, Okayama Prefecture, Japan. 
pace. Due to the relatively thick and opaque carapace of $P$. inujimensis, it is possible that the testes were not visible in some whole males, so the ratio of males to females for that species may be an underestimate. The appendages were mounted in glycerin on glass slides with cover slips sealed with an acryloid varnish (B72, ethyl methacrylate copolymer), then drawn with the aid of a camera lucida. Carapaces were mounted on stubs and sputter-coated with gold prior to being viewed using a JEOL JSM-5310 scanning electron microscope. All figured material is deposited in the University Museum, the University of Tokyo (UMUT), Bunkyo-ku, Tokyo, Japan.

Terminology of the hemipenes follows that of Martens (1998) and terminology of the appendages follows that of Broodbakker and Danielopol (1982), Martens (1987), and Meisch (2000).

\section{Results and Discussion}

Three abundant species were collected: Dolerocypria mukaishimensis Okubo, 1980, Paracypria inujimensis (Okubo, 1980), and Ishizakiella supralittoralis (Schornikov, 1974) (Fig. 2). Dolerocypria mukaishimensis was the most abundant species, forming $45 \%$ of the sample; $P$. inujimensis formed $36 \%$ of the sample, and $I$. supralittoralis, $19 \%$. Of D. mukaishimensis, $70 \%$ of individuals were adults, $11.4 \%$ were instar A-1, 11.4\% were instar A-2, and 7.3\% were instar A-3; $26 \%$ of the adults were males. Of $P$. inujimensis, $86 \%$ of individuals were adults, $10 \%$ were instar A-1, $3 \%$ were instar A-2, and $1 \%$ were instar A-3; at least $13.5 \%$ of the adults were male. Of $I$. supralittoralis, $17 \%$ of individuals were adults, $33 \%$ were instar A-1, $33 \%$ were instar A-2, and $17 \%$ were instar A-3; $22 \%$ of the adults were males, but due to the small sample size (nine specimens) this is probably an inaccurate representation of the true male-to-female ratio. Females had eggs and a smaller number of A-8 instars in the posterior brood pouches. The carapaces of all adult $I$. supralittoralis were badly fouled, with a thick, uneven crust covering most of the surface, especially thick on the posterior part of the carapace. The juveniles were mostly clean.

\section{Distribution and ecology of the three species}

Paracypria inujimensis

This species is known from only two localities, including Ushimado, Okayama Prefecture (see above). Okubo (1980) reported it from an unspecified locality on Inujima Island, a small island just to the south of Okayama city and approximately $11 \mathrm{~km}$ southwest of Ushimado. At both localities it is abundant. Its known distribution is very restricted, a possible result of collecting bias.

This species seems to be tolerant of marine and brackish conditions. In addition to the type locality, it was abundant in the intertidal zone of a stony shore where thick algae were growing at Inujima Island, presumably in a marine environment (Okubo 1980).

Co-existing species include: D. mukaishimensis and I. supralittoralis (at Ushimado).

\section{Dolerocypria mukaishimensis}

Including Ushimado, Okayama Prefecture (see above), this species is known 
from five areas. Okubo (1980) recovered one specimen, upon which he based the species description, at the Mukaishima Biological Station, Hiroshima Prefecture. Because Okubo found only one specimen, that locality is probably a marginal habitat for this species. Okubo (2000) reported D. mukaishimensis from the lowermost 4 $\mathrm{km}$ of the Asahi River in Okayama Prefecture. Hiruta and Smith (2001) found $D$. mukaishimensis together with I. supralittoralis in great abundance in Akkeshi, eastern Hokkaido (see map in Hiruta and Smith 2001). Nakao and Tsukagoshi (2002) recovered D. mukaishimensis from the Obitsu River Estuary, central Japan. Additionally, Ikeya and Hanai (1982) reported specimens of "Cyprididae n. sp." at 26 (of 93) sampling stations in Hamana-ko Bay, Shizuoka Prefecture (see maps in Ikeya and Hanai 1982). The figures and photographs of "Cyprididae n. sp." look remarkably similar to D. mukaishimensis and further investigation of this site may well confirm these two species are the same.

Okubo $(1980,2000)$ suggested that $D$. mukaishimensis is not common in Japan. Although it was found in high abundance at three of the hitherto five known collecting sites, its documented distribution is very restricted. This is probably a result of collecting bias as brackish-water habitats have not been widely studied in Japan.

The habitats of $D$. mukaishimensis vary from marine (Okubo 1980) to brackish (Okubo 2000; Hiruta and Smith 2001; Nakao and Tsukagoshi 2002; this paper), but it reaches its highest abundance in brackish water (e.g., Ushimado; see above). Okubo (1980) recovered a specimen from marine muddy sand and later found this species in the muddy sand of the lower reaches of the Asahi River (Okubo 2000). Hiruta and Smith (2001) reported it living amongst a thick layer of filamentous algae growing over cobble-filled wire crates just below the surface in an artificial pool at Akkeshi. Later sampling of the water at Akkeshi revealed that the salinity varied from 12 to $23 \%$ over a small distance, but the species was abundant at all sites.

The co-existing species of D. mukaishimensis include: I. supralittoralis (at Akkeshi and Ushimado) and $P$. inujimensis (at Ushimado).

\section{Ishizakiella supralittoralis}

This species has previously been reported from 13 sites: two sites in the Kuril Islands (Schornikov 1974), five sites in Hokkaido (Tsukagoshi 1994; Hiruta and Smith 2001), one site in Russia [Russky Island off Vladivostok (Schornikov 1974); see map in Tsukagoshi (1994)], one site on the northeastern coast of Honshu [Takase River (Yamaguchi 2000)], and four sites in the Amakusa Islands, western Kyushu (Yamaguchi 2000). This report of I. supralittoralis from the Inland Sea of Japan is the first record of the species and of the genus from that area. Other authors have not noted its ecological characteristics, other than to record it as a brackish-water species. As with $D$. mukaishimensis, it appears to have a high tolerance to various salinity conditions.

Co-existing species include: D. mukaishimensis (at Ushimado and Akkeshi) and $P$. inujimensis (at Ushimado).

\section{Males of $D$. mukaishimensis and $P$. inujimensis}

Okubo (1980) stated that males were unknown for both $D$. mukaishimensis and 
$P$. inujimensis, but he only found one specimen of the former. Okubo (2000) and Hiruta and Smith (2001) did not comment on the presence of males of D. mukaishimensis, but the males have recently been discovered and described by Nakao and Tsukagoshi (2002). The present study has shown that males of $D$. mukaishimensis are relatively abundant at Ushimado, forming $26 \%$ of the adult population in June.

Okubo (1980) stated that $P$. inujimensis was abundant at Inujima Island, but yet he did not find any males in a sample taken in July. On the contrary, the present study revealed that at least $13.5 \%$ of the adult population are males in June at Ushimado. Since both samples were taken at about the same time of the year, it is unlikely that seasonal variation in the number of males accounts for the difference. It is possible that the population of $P$. inujimensis at Inujima Island is parthenogenetic, in contrast to the sexual population at Ushimado. Such differences in the mode of reproduction between populations of a species have been widely documented in freshwater ostracods (Horne et al. 1998). Although parthenogenesis is not common in marine or brackish-water ostracods, it is thought to occur in the marine candonid Paracypris polita Sars, 1866 (Horne et al. 1998). Another possibility is that Okubo (1980) missed the males in his sample; the testes are only faintly visible through the carapace of $P$. inujimensis, and they may not be visible in some males (see above). Paratypes of $P$. inujimensis from the type locality studied by Wouters (1998) included males, which supports the latter possibility.

\section{Ishizakiella around Japan}

There are presently three species of Ishizakiella known to live in brackishwater habitats around the Japanese Archipelago: I. supralittoralis around Hokkaido, Honshu, and Kyushu; I. miurensis (Hanai, 1957) around Honshu and Kyushu; and I. ryukyuensis Tsukagoshi, 1994 around the Nansei Islands (Tsukagoshi 1994; Yamaguchi 2000). Other than that all three species live in brackish water of varying salinity, very little is known of their ecology, and previous authors have assumed that they have similar habitat requirements (e.g., Tsukagoshi 1994; Yamaguchi 2000). Brackish-water habitats are often influenced to a greater or lesser degree by the sea and, as a result, their environmental parameters can vary considerably both spatially and through time (over a day, a month, or a year). To fully understand differences in brackish-water habitats, a long period of environmental monitoring is thus required, something which has not been completed at any Ishizakiella locality. Both $I$. supralittoralis and I. miurensis are widely distributed around Japan, with ranges that overlap considerably, and they have been found at localities very close to each other [e.g., Tobase Island (Yamaguchi 2000)]; however, I. miurensis has so far not been reported with $I$. supralittoralis, nor with D. mukaishimensis, which appears to coexist relatively commonly with $I$. supralittoralis. This suggests that these two species of Ishizakiella are separated by different habitat preferences rather than geography and don't directly compete with each other.

Yamaguchi (2000) suggested that I. supralittoralis was the earliest Ishizakiella species to arrive in Japan, based on mitochondrial CO1 gene sequences and the fossil record. He considered that I. miurensis migrated to the Japanese Archipelago at a later date and colonized the area around Honshu. A likely scenario is that after $I$. supralittoralis colonized the Japanese Archipelago, I. miurensis arrived and colonized brackish-water environments with environmental parameters different to 
those already colonized by I. supralittoralis. Ishizakiella miurensis may have displaced I. supralittoralis in the latter species' more marginal habitats, but in ideal habitats for $I$. supralittoralis it would have been very difficult for $I$. miurensis to displace an already established species. The currently known distribution of these two species is probably a result of available habitat types and collection bias concerning both locality and habitat type.

\section{Systematic description}

Because males of $P$. inujimensis have not previously been figured, a description of them is given below. Systematic position of this species in the class Ostracoda Latreille, 1806 is currently accepted as follows: order Podocopida G. W. Müller, 1894, suborder Cypridocopina Jones, 1901, superfamily Cypridoidea Baird, 1845, family Candonidae Baird, 1845, subfamily Paracypridinae Sars, 1923, tribe Thalassocypridini Hartmann and Puri, 1974, and genus Paracypria Sars, 1910.

Paracypria inujimensis (Okubo, 1980)

(Figs 2-5)

Thalassocypria inujimensis Okubo, 1980: 22.

Paracypria inujimensis: Wouters 1998: 119.

Type material and type locality. Holotype: female MO-1152, LV (82-42), RV (83-41). Paratype: female MO-1153 with incomplete measurements, LV (82-?), RV (unknown). The holotype and the paratype were collected by Okubo (1980) on 18 July 1978 from an unspecified locality off Inujima Island, Okayama Prefecture, Japan.

Figured material. Three dissected males UMUT RA 28188-28190; male left and right valves UMUT RA 28191; whole male carapace UMUT RA 28192. These material was collected by the authors on 19 June 2001 from Ushimado, Okayama (see "Study area" section above for detailed description).

Description of male (Figs 2-5). Carapace. Length $785-815 \mu \mathrm{m}$, height $370-389$ $\mu \mathrm{m}$. Carapace of male similar in shape to that of female, but maximum width slightly farther posteriorly, at midlength [maximum width of female at approximately anterior two fifths (Okubo 1980; this study)]. Colouration variable in single specimen and between individuals, generally patchy ranging from opaque white to black, but mostly dark blue-grey. Carapace relatively thick and elongate, with well

Fig. 2. A-C, Dolerocypria mukaishimensis Okubo, 1980: A, external lateral view of right valve (male 010619/2019); B, internal lateral view of left valve (male UMUT RA 28194); C, ventral view of whole carapace, anterior to right (male UMUT RA 28195). D-G, Paracypria inujimensis (Okubo, 1980): D, external lateral view of right valve (male UMUT RA 28189); E, internal lateral view of left valve (male UMUT RA 28191); F, ventral view of whole carapace, anterior to right (male UMUT RA 28192); G, detail of carapace surface (male UMUT RA 28189). H-J, Ishizakiella supralittoralis (Schornikov, 1974): $\mathrm{H}$, internal lateral view of left valve (female UMUT RA 28196); I, external lateral view of right valve (female UMUT RA 28197); J, external lateral view of left valve (female UMUT RA 28197). Scale bar $=200 \mu \mathrm{m}$ for A-F, H-J and $13 \mu \mathrm{m}$ for $\mathrm{G}$. 


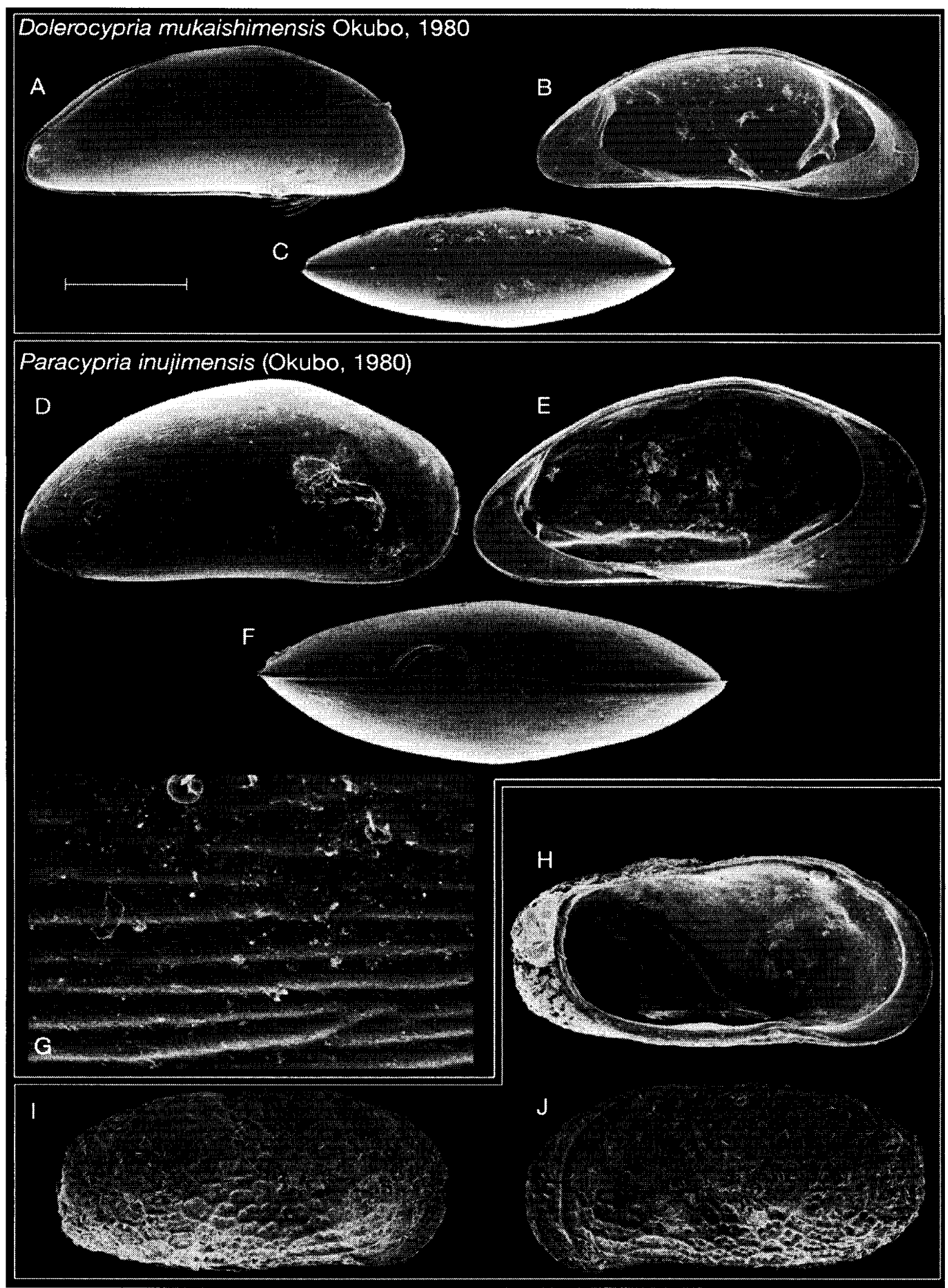




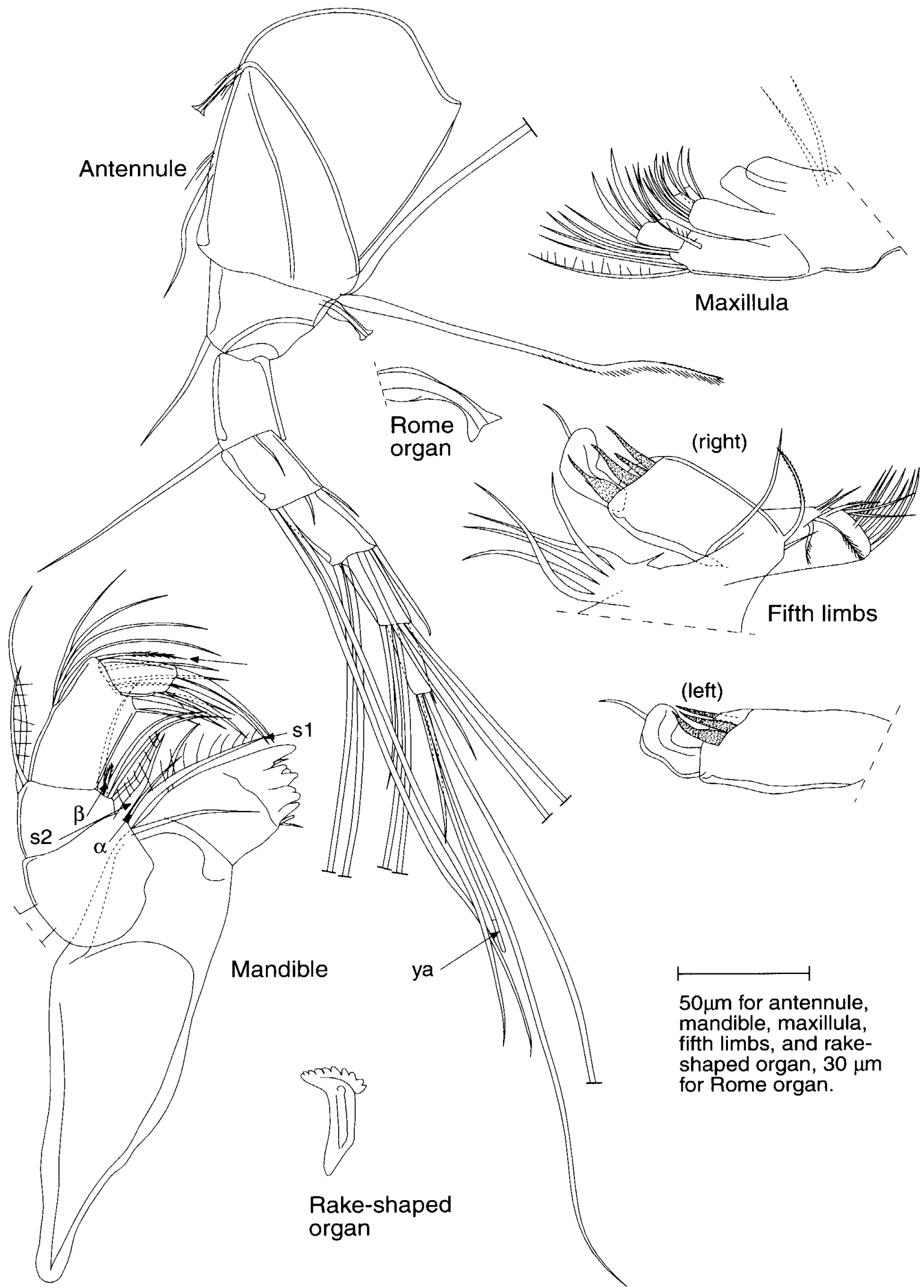

Fig. 3. The male of Paracypria inujimensis (Okubo, 1980). Antennule (UMUT RA 28189), Rome organ (UMUT RA 28188), mandible (UMUT RA 28188), rake-shaped organ (UMUT RA 28188), maxillula (UMUT RA 28189), and fifth limbs (UMUT RA 28189). 


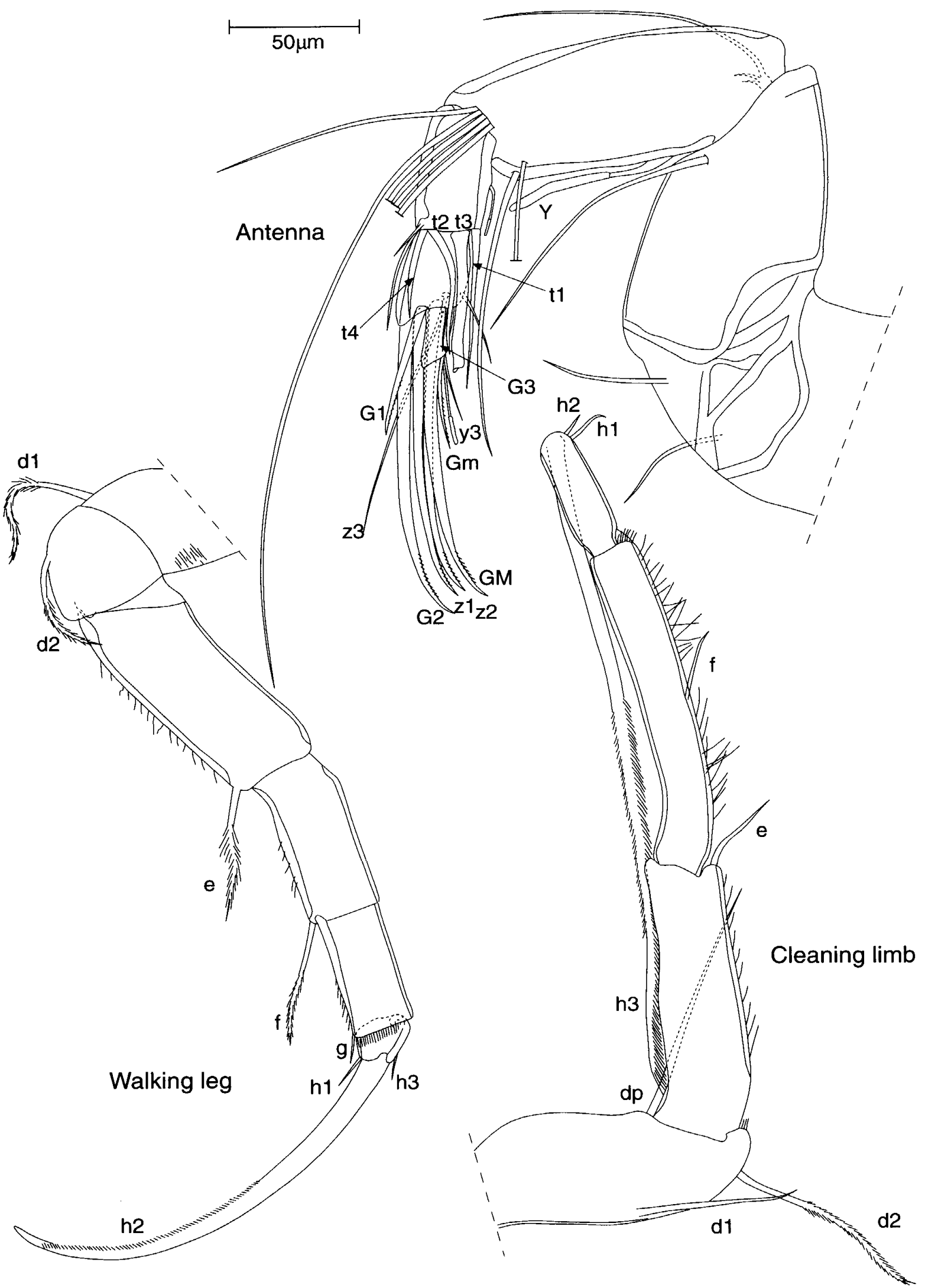

Fig. 4. Male of Paracypria inujimensis (Okubo, 1980). Antenna, right (UMUT RA 28189), walking leg (UMUT RA 28189), and cleaning limb (UMUT RA 28189). 


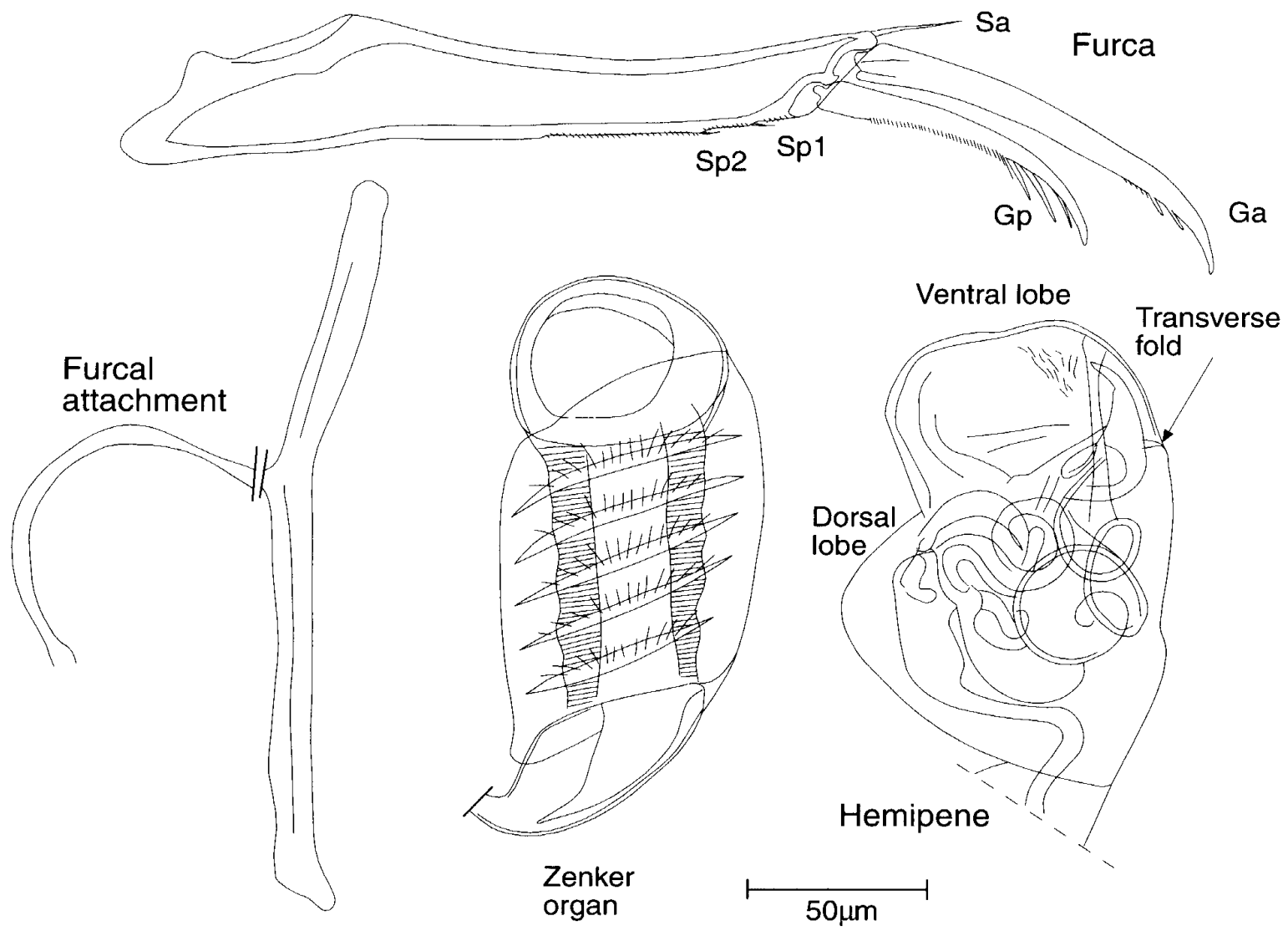

Fig. 5. Male of Paracypria inujimensis (Okubo, 1980). Furca and furcal attachment (UMUT RA 28188), hemipenis (UMUT RA 28189), and Zenker organ (UMUT RA 28190).

rounded anterior margin and narrowly rounded posterior margin; maximum height just anterior of midlength. Dorsal margin curved, sloping away to narrow posterior margin. Ventral margin slightly concave. Hinge adont. In ventral view left valve slightly longer than right and overlapping it along ventral margin. Testes faintly visible in posterior part of carapace. Surface of carapace covered with many longitudinal, slightly wavy, fine striations.

Antennule. Consisting of 7 podomeres. First podomere large with 2 long ventral-apical setae and 1 short seta and 1 aesthetasc on dorsal edge. Second podomere small, wider than long, with 1 seta on dorsal-apical corner and relatively large Rome organ [= small outgrowth of Okubo (1980)] in ventral proximal position. Rome organ with bulbous base and funnel-shaped distal end. Third podomere with 1 ventral-apical seta and 1 tiny mid-apical seta. Fourth podomere with 2 long dorsal-apical setae, 1 short ventral-apical seta, and 1 short mid-apical seta. Fifth podomere with 2 long dorsal-apical setae, 1 short ventral-apical seta, and 1 medium-length mid-apical seta. Sixth podomere terminating with 4 long and 1 short setae. Final podomere with 2 long setae, 1 short seta, and long ya aesthetasc.

Antenna. Protopodite well developed and broad with 1 long seta near inner apical corner and two setae on inner edge. Main seta of exopodite not reaching end of 1st endopodite podomere and accompanied by 2 much smaller setae. $Y$ aesthetasc long, reaching almost to end of 1st endopodite podomere. Only 4 long natatory 
setae, extending just past terminal claws; 1 additional, shorter natatory seta reaching to base of terminal podomere. First endopodite podomere with 2 long setae on ventral apical corner. Second endopodite podomere with 1 small aesthetasc on inner edge and terminating with setae $t 1-4$. Seta $t 1$ long and on inner-apical corner. Seta $t 2$ long and broad with rounded end, and seta $t 3$ nearly as long as $t 2$ but thinner with tapering end. Both $t 2$ and $t 3$ located on apical inner edge of podomere. Seta $t 4$ located on outer-apical corner and approximately as long as next podomere. $G 2, z 1$, and $z 2$ claws of next podomere all of similar length, well developed and robust, curving distally. $G 1$ claw short and $z 3$ seta approximately $3 / 4$ length of large claws. $G 3$ seta small, not reaching to end of final podomere. $G m$ claw of final podomere thin and short. Claw $G M$ well developed, reaching to same point as large claws on previous podomere.

Mandible. Mandibular palp 4-segmented, with elongate 3rd podomere. s2 seta relatively reduced and shorter than $s 1$ seta. $\alpha$ seta long and thin. $\beta$ seta short and thin and covered with many fine setules. $\gamma$ seta thin and slightly longer than next podomere. Branchial plate with 6 long setae.

Rake-shaped organs. Rake-shaped organs each with thick root, and 10 teeth along distal edge.

Maxillula. Segmented palp and 3 well developed endites present. First podomere of palp terminating in 6 setae on outer edge and 1 subapical seta. Final podomere terminating in 2 stout setae and 4 thin setae.

Fifth limbs. Anterior endite terminating in approximately 14 setae. Palps with subapical short, flat, translucent setae covered in tiny setules. Right palp with 4 of these setae on outer edge; left palp with 2 such setae on outer edge and 1 seta on inner edge. Grasping hooks asymmetrical, small and rounded, with 1 long setae on posterior edge; left hook slightly more tightly curved than right hook and with more sinuous outer edge.

Walking leg. Relatively large, elongate. Base of leg with both $d 1$ and $d 2$ setae. Setae $e$ and $f$ approximately same length as preceeding podomere. Setae $g, h 1$, and $h 3$ all tiny. Claw $h 2$ well developed.

Cleaning limb. Large and elongate. First podomere with setae $d p, d 1$, and $d 2$. Second podomere with short $e$ seta. Third podomere the most elongate and slightly curved at base, with short $f$ seta at midlength, and no $g$ seta. Final podomere elongate and bearing small $h 1$ seta, slightly smaller $h 2$ seta, and well developed, very long $h 3$ seta; $h 3$ seta approximately as long as final 3 podomeres.

Furca. Robust with short $S a$ seta, well developed $G a$ and $G p$ claws, and two tiny $S p$ setae. $G a$ claw longer and thicker than $G p$ claw, latter with 3 spines towards distal end. Furcal attachment with thick, almost straight anterior branch and much thinner, tightly curved posterior branch.

Zenker organs. Large and broad, with round proximal end almost as wide as main body of organ. Internally, core wide and containing 5 wide rings of spines. Distal triangular process large, wide, and rounded.

Hemipenes. Broad with narrow base and maximum width at about $1 / 3$ of length from base. Inner edge curved. Ventral lobe large with almost straight edges and well rounded corners. Outer edge with large, acutely curved dorsal lobe. Prelabyrinthal inner spermiduct wide. During erection, ventral lobe bent towards outer edge, giving distinct bend to inner edge at transverse fold, and dorsal lobe becoming less inflated. 


\section{Acknowledgments}

The authors thank David J. Horne (University of Greenwich, UK) for help with identifications of specimens and the reviewers of the manuscript: Louis S. Kornicker (Smithsonian Institution, USA) and Akira Tsukagoshi (Shizuoka University, Japan). RJS thanks JSPS and the Royal Society (UK) for funding.

\section{References}

Baird, W. 1845. Arrangement of the British Entomostraca, with a list of species, particularly noticing those which have as yet been discovered within the bounds of the club. Transactions of the Berwickshire Naturalists' Club 2: 145-148.

Broodbakker, N. W. and Danielopol, D. L. 1982. The chaetotaxy of Cypridacea (Crustacea, Ostracoda) limbs: Proposals for a descriptive model. Bijdragen tot de Dierkunde 52: 103-120.

Hartmann, G. and Puri, H. S. 1974. Summary of neontological and paleontological classification of Ostracoda. Mitteilungen aus dem Hamburgischen Zoologischen Museum und Institut 70: 7-73.

Hiruta, S. and Smith, R. J. 2001. Living freshwater and shallow marine Ostracoda in Eastern Hokkaido, Japan. Pp. 107-125. In: Ikeya, N. (Ed.) Guidebook of Excursions. The Organising Committee of the 14th International Symposium on Ostracoda, Shizuoka, $147 \mathrm{pp}$.

Horne, D. J., Baltanás, A. and Paris, G. 1998. Geographical distribution of reproductive modes in living non-marine ostracods. Pp. 77-99. In: Martens, K. (Ed.) Sex and Parthenogenesis; Evolutionary Ecology of Reproductive Modes in Non-marine Ostracods. Backhuys Publishers, Leiden, $335 \mathrm{pp}$.

Ikeya, N. and Hanai, P. 1982. Ecology of Recent ostracods in the Hamana-ko region, the Pacific coast of Japan. The University Museum, University of Tokyo, Bulletin (20): 15-59.

Ishizaki, K. 1969. Ostracodes from Shinjiko and Nakanoumi, Shimane Prefecture, Western Honshu, Japan. Science Reports of the Tohoku University. Second Series, Geology 41: 197-224.

Jones, T. R. 1901. On some Carboniferous shale from Siberia. Geological Magazine (4) 8: 433-436.

Latreille, P. A. 1806-07. Genera Crustaceorum et Insectorum. Tomus 1 (1806), Tomus 2 (1807). Paris, $303 \mathrm{pp}$.

Martens, K. 1987. Homology and functional morphology of the sexual dimorphism in the antenna of Sclerocypris Sars, 1924 (Crustacea, Ostracoda, Megalocypridinae). Bijdragen tot de Dierkunde 57: 183-190.

Martens, K. 1998. General morphology of non-marine ostracods. Pp. 57-75. In: Martens, K. (Ed.) Sex and Parthenogenesis: Evolutionary Ecology of Reproductive Modes in Non-marine Ostracods. Backhuys Publisers, Leiden, $335 \mathrm{pp}$.

Meisch, C. 2000. Freshwater Ostracoda of Western and Central Europe. Süßwasserfauna von Mitteleuropa 8/3. Spektrum Akademischer Verlag, Heidelberg, Berlin, 522 pp.

Müller, G. W. 1894. Die Ostracoden des Golfes von Neapel und der angrezenden Meeres-Abschnitte. Fauna und Flora des Golfes von Neapel und der angrenzenden Meeres-Abschnitte, Herausgegeben von der Zoologischen Station zu Neapel 21: 1-404.

Nakao, Y. and Tsukagoshi, A. 2002. Brackish-water ostracods from the Obitsu River Estuary, Central Japan. Species Diversity 7: 67-115.

Okubo, I. 1980. Three new species of the family Candonidae (Ostracoda) from the Inland Sea 
of Japan. Proceedings of the Japanese Society of Systematic Zoology (18): 18-27.

Okubo, I. 2000. Subclass Ostracoda Latreille, 1806. Pp. 96-123. In: Mizuno, T. and Takahashi, E. (Eds) An Illustrated Guide to Freshwater Zooplankton in Japan. Tokai University Press, Tokyo, xxii +551 pp. [In Japanese]

Sars, G. O. 1910. Zoological results of the Third Tanganyika Expedition, conducted by Dr. W. A. Cunnington 1904-1905. Report on the Ostracoda. Proceedings of the Zoological Society of London 1910: $732-760$.

Sars, G. O. 1923. An Account of the Crustacea of Norway with Short Descriptions and Figures of All the Species. Volume 9 (Ostracoda) (Parts 3-4). Bergen, pp. 33-72.

Schornikov, E. I. 1974. On the study of Ostracoda (Crustacea) from the intertidial zone of the Kurile Islands. Transactions of the Academy of Science of the USSR, Far East Science Center, Institute of Marine Biology 1: 137-214. [In Russian with English abstract]

Tsukagoshi, A. 1994. Natural history of the brackish-water ostracode genus Ishizakiella from East Asia: Evidence for heterochrony. Journal of Crustacean Biology 14: 295-313.

Wouters, K. 1998. A new thalassocypridine genus (Crustacea, Ostracoda) from brackish waters in the Indian and Pacific Oceans, with the description of a new species. Bulletin de l'Institut Royal des Sciences Naturelles de Belgique, Biologie 68: 111-122.

Yamaguchi, S. 2000. Phylogenetic and biogeographical history of the genus Ishizakiella (Ostracoda) inferred from mitochondrial $\mathrm{CO} 1$ gene sequences. Journal of Crustacean Biology 20: 357-384. 